\title{
Isolation and characterization of nine microsatellite markers for the red alga Corallina officinalis
}

Ana I. Tavares1 · Katy R. Nicastro1 · Regina Kolzenburg2 · Federica Ragazzola2 • Rita Jacinto1 • Gerardo I. Zardi3

\begin{abstract}
We report the development of nine polymorphic microsatellite markers for Corallina officinalis (Linnaeus, 1758), a calcifying intertidal red alga and important ecosystem engineer spread along the North East Atlantic. Characterization and analysis of loci were made using 15 individuals of $C$. officinalis from populations in Iceland and the UK. The average number of alleles per locus was 3.78 (range 2-6) and mean of gene diversity was 0.58 (range 0.38-0.77). The set of microsatellites developed here will provide a useful molecular tool for population genetic and conservation studies.
\end{abstract}

Keywords Corallina officinalis · Genetic diversity $\cdot$ Microsatellites $\cdot$ Red algae $\cdot$ Marginal population Corresponding author: Ana I. Tavares aimtavares@ualg.pt

\section{Introduction}

Within the red algae, Corallinales (Rhodophyta) is one of the most species rich orders [1, 2]. Given their role as bioengineers and of their sensitivity to climate change and ocean acidification, species in the Corallinales are of great ecological relevance in various marine, wave-exposed littoral and sublittoral habitats [3, 4]. They are also abundant components in fossil and sub-fossil records, thus representing valuable indicators of paleoenvironmental conditions and providing important information to contextualize ongoing climatic changes [5-8]. Corallina officinalis Linnaeus, 1758 (Corallinales, Rhodophyta) is an abundant and widespread calcified geniculate coralline alga on rocky shores in the North Atlantic [9-11]. The distribution of $C$. officinalis along NE Atlantic shores extends from northern Spain and the Azores, in the south, to northern Norway, Iceland and southern Greenland, in the north $[10,12]$. The dense turfs created by this species provide shelter in hydrodynamically stressful habitats for many invertebrates [13]. Moreover, C. officinalis contributes

to carbon dioxide fluxes within the ocean, thus playing a critical role in the carbon cycle of coastal marine ecosystems [14].

Despite its ecological importance, genetic studies for this species are limited [15]. These have used mitochondrial and nuclear sequence data for barcoding, taxonomy, mitogenomics and phylogeny [2, 9, 10, 16-19]. Only very recently have population genetic patterns of $C$. officinalis been investigated

[20, 21]. Specifically, novel SNP markers were developed and used to assess population structure based on five locations throughout the NE Atlantic distribution of the species and, at finer spatial scale, along UK shores. Here, with the aim of providing new useful tools using methods previously unutilised for this group, we developed and characterized nine polymorphic microsatellite markers for the red algae $C$. officinalis. 


\section{Methods}

All samples were hand-collected during low tide from rocky substrate. Tissue was stored in silica drying crystals prior to extraction of DNA. Genomic DNA was extracted from eight individuals, four collected in Iceland (Stafnesviti $63^{\circ} 58^{\prime} 06.5^{\prime \prime} \mathrm{N} 22^{\circ} 45^{\prime} 03.0^{\prime \prime} \mathrm{W}$ and Stafnes $63^{\circ} 58^{\prime} 28.1^{\prime \prime} \mathrm{N} 22^{\circ} 45^{\prime} 13.8^{\prime \prime} \mathrm{W}$ ) and four in the UK (Margate $\left.51.393200^{\circ} \mathrm{N} 01.383820^{\circ} \mathrm{E}\right)$ using the PowerSoil DNA Isolation Kit (MoBio Laboratories, Carlsbad, CA) in accordance with the manufacturer's instructions. Extracted DNA was sent to Ecogenics GmbH molecular marker services (Zurich- Schlieren, Switzerland) to isolate and design microsatellite markers. Genomic DNA sizeselected fragments were enriched for simple sequence repeat (SSRs) content by using magnetic streptavidin beads and biotin-labeled CT, GT, AGG, GGT GATA and GTAT repeat oligonucleotides. The SSR-enriched library was analyzed on an Illumina MiSeq platform using the Nano $2 \times 250$ v2 format. After assembly,

2444 contigs or singlets contained a microsatellite insert with a tetra- or a trinucleotide of at least six repeat units or a dinucleotide of at least ten repeat units. Out of 1129 microsatellite candidates, 20 were designed and tested. Out of these, nine pairs of primers showed polymorphism. The identified, polymorphic primers were further characterized using the eight and seven $C$. officinalis individuals from Icelandic and UK populations respectively (Table 1).The $10 \mu \mathrm{L}$ volume PCR mix contained $\pm 10 \mathrm{ng}$ of DNA, $0.3 \mu \mathrm{M}$ of each primer labelled with a florescent marker, $200 \mu \mathrm{M}$ dNTPs, $1.0 \mu \mathrm{l}$ of 10× PCR Buffer with $15 \mathrm{mM} \mathrm{MgCl} 2$ and $0.5 \mathrm{U}$ of HotStar Taq. Cycling conditions consisted of an initial denaturing step of $15 \mathrm{~min}$ at $95{ }^{\circ} \mathrm{C}$, followed by 35 cycles of $30 \mathrm{~s}$ at $95{ }^{\circ} \mathrm{C}, 45 \mathrm{~s}$ at $56^{\circ} \mathrm{C}$ annealing temperature, $45 \mathrm{~s}$ at $72{ }^{\circ} \mathrm{C}$, and a final elongation step at 72 ${ }^{\circ} \mathrm{C}$ for 30 min. The allele sizes were determined on an ABI3730 (Applied Biosystems), using GeneScan ${ }^{\mathrm{TM}}-500$ LIZ Size Standard. Alleles were scored manually using STRand [22]. GENETIX software version 4.05 [23] was used to estimate observed (HO) and expected (HE) heterozygosities. The Hardy-Weinberg expectation (HWE) and linkage disequilibrium were tested using Genepop 4.2 [24] and the resulting p values were Bonferroni-corrected for multiple comparisons $(\mathrm{p}<0.0016)$.

\section{Results and discussion}

All microsatellites described in this study were polymorphic (Table 1). The number of alleles per locus ranged between 1-6 and 1-5 for the populations from Iceland and the UK, respectively. For the Icelandic populations, expected and observed heterozygosities ranged from 0.37 to 0.69 and from 0.25 to 0.88 respectively (Table 1) while for the UK populations, values ranged from 0.41 to 0.77 and from 0 to 0.86 (Table 1). The highest genetic diversity was found in the UK population, with Coroff_8333 being the most informative locus. The lowest genetic diversity values were given by Coroff_1036 and Coroff_1640 and by Coroff_1258 for Iceland and UK populations respectively. For all loci pairs, we tested for linkage disequilibrium between them, using 1000 replicates and for two pairs (Coroff_2347-Coroff_3261; Coroff_1640-Coroff_7707) there was no significant deviation after Bonferroni correction. Significant deviation from HWE was found for Coroff_11062 in the UK population. Relatively high values of observed heterozygosity recently reported for SNP markers [20] suggest polyploidy in C. officinalis. It is important to note that potential polyploidy could significantly affect our ability to reliably utilise codominant scoring and thus interpretation of peak patterns [25]. Most SNP markers recently developed for C. officinalis show significant departures from HWE [20]; in our study, significant deviation was 
limited to one locus, highlighting the value of the set of microsatellites developed here to investigate ecological and evolutionary dynamics of this intertidal bioengineer associated with habitat contraction and environmental change.

Acknowledgements This research was funded by projects UID/ Multi/04326/2013, IF/01413/2014/CP1217/CT0004 from the Fundação para a Ciência e Tecnologia (FCT-MEC, Portugal) and RDF from University of Portsmouth and further supported by the South African Research Chairs Initiative (SARChI) of the Department of Science and Technology and the National Research Foundation and a scholarship from the South African National Research Foundation (NRF). We thank C.D. McQuaid and C. Yesson for their comments.

\section{References}

1. Guiry MD, Guiry GM (2017) AlgaeBase. World-wide electronicpublication, National University of Ireland, Galway. http://www. algae base.org. Accessed 12 Dec 2017

2. Walker RH, Brodie J, Russell S, Irvine LM, Orfanidis S (2009)Biodiversity of coralline algae in the Northeastern Atlantic. J Phycol297:287-297. https ://doi.org/10.1111/j.1529-8817.2008.0637

3. Broom JE, Hart DR, Farr TJ, Nelson WA, Neill KF, Harvey AS, Woelkerling WJ (2008) Utility of psbA and nSSU for phylogeneticreconstruction in the Corallinales based on New Zealand taxa.Mol Phylogenet Evol 46:958-973. https ://doi.org/10.1016/j.ympev.2007.12.016

4. Mccoy SJ, Kamenos NA (2015) Coralline algae (Rhodophyta)in a changing world: integrating ecological, physiological, and geochemical responses to global change. J Phycol 51:6-24. https://doi.org/10.1111/jpy.12262

5. Braga JC, Aguirre J (2001) Coralline algal assemblages in upperNeogene reef and temperate carbonates in Southern Spain. Palaeogeogr Palaeoclimatol Palaeoecol 175:27-41. https ://doi.org/10.1016/S0031 -0182(01)00384 -4

6. Abbey E, Webster JM, Braga JC, Sugihara K, Wallace C, Iryu Y,Potts D, Done T, Camoin G, Seard C (2011) Variation in deglacialcoralgal assemblages and their paleoenvironmental significance:IODP Expedition 310, "Tahiti Sea Level”. Glob Planet Change76:1-15. https ://doi.org/10.1016/j.glopl acha.2010.11.005

7. Aguirre J, Braga JC, De Reviers B, Woelkerling WJ (2012) Reassessmentof Lemoine's newly discovered types of fossil corallines (Corallinales, Rhodophyta) preserved at the Muséum nationald'histoire naturelle, Paris. Cryptogam Algol 33:289-326. https ://doi.org/10.7872/crya.v33.iss3.2012.289

8. Novak V, Santodomingo N, Rösler A, Martino E, Braga JC, TaylorPD, Johnson KG, Renema W (2013) Environmental reconstruction of a late Burdigalian (Miocene) patch reef in deltaic deposits(East Kalimantan, Indonesia). Palaeogeogr Palaeoclimatol Palaeoecol374:110-122. https ://doi.org/10.1016/j.palae o.2013.01.009

9. Brodie J, Walker RH, Williamson C, Irvine LM (2013) Epitypificationand redescription of Corallina officinalis L., the type of the genus, and C. elongata Ellis et Solander (Corallinales, Rhodophyta).Cryptogam Algol 34:49-56. https ://doi.org/10.7872/crya. v34.iss 1.2013 .49

10. Williamson CJ, Walker RH, Robba L, Yesson C, Russell S, IrvineLM, Brodie J (2015) Toward resolution of species diversity and distribution in the calcified red algal genera Corallina and Ellisolandia(Corallinales, Rhodophyta). Phycologia 54:2-11. https :// doi.org/10.2216/14-024.1

11. Williamson CJ, Perkins R, Voller M, Yallop ML, Brodie J (2017)The regulation of coralline algal physiology, an in situ study of Corallina officinalis (Corallinales, Rhodophyta). Biogeosciences.https ://doi.org/10.5194/bg-2017-135

12. Pardo C, Peña V, Barreiro R, Bárbara I (2015) A molecular andmorphological study of Corallina sensu lato (Corallinales, Rhodophyta)in the Atlantic Iberian Peninsula. Cryptogam Algol36:31-54. https ://doi.org/10.7872/crya.v36.iss1.2015.31

13. Nelson WA (2009) Calcified macroalgae-critical to coastal ecosystemsand vulnerable to change: a review. Mar Freshw Res 60:787-801. https ://doi.org/10.1071/MF083 35

14. van der Heijden LH, Kamenos NA (2015) Reviews and syntheses:calculating the global contribution of coralline algae to total carbon burial. Biogeosciences 12:6429-6441. https ://doi.org/10.5194/bg-12-6429-2015

15. Kim KM, Yang EC, Kim JH, Nelson WA, Yoon HS (2015) Completemitochondrial genome of a rhodolith, Sporolithon durum 
(Sporolithales, Rhodophyta). Mitochondrial DNA 26:155-156.https ://doi.org/10.3109/19401 736.2013.81950 0

16. Robba L, Russell SJ, Barker GL, Brodie J (2006) Assessing theuse of the mitochondrial cox 1 marker for use in DNA barcoding of red algae (Rhodophyta). Am J Bot 93:1101-1108. https ://doi.org/10.3732/ajb.93.8.1101

17. Hind KR, Saunders GW (2013) A molecular phylogenetic study ofthe tribe Corallineae (Corallinales, Rhodophyta) with an assessment of genus-level taxonomic features and descriptions of novelgenera. J Phycol 49:103-114.

https://doi.org/10.1111/jpy.12019

18. Hind KR, Gabrielson PW, Lindstrom SC, Martone PT (2014)Misleading morphologies and the importance of sequencing type specimens for resolving coralline taxonomy (Corallinales, Rhodophyta):Pachyarthron cretaceum is Corallina officinalis. J Phycol 50:760-764. https ://doi.org/10.1111/jpy.12205

19. Corallinales, Rhodophyta (2016) Complete mitochondrial genomeof the geniculate calcified red alga, Corallina officinalis. MitochondrialDNA Part B 1:326-327. https ://doi.org/10.1080/23802359.2016.11720 48

20. Yesson C, Jackson A, Russell S et al (2018) SNPs reveal geographicalpopulation structure of Corallina officinalis (Corallinaceae,Rhodophyta). Eur J Phycol. https ://doi.org/10.1080/09670262.2017.14023 73

21. Glynn WH (2018) Population structure in the red calcifying algaCorallina officinalis in the North Atlantic: implications in a timeof global climate change. Thesis project for the MRes in Biodiversity,Evolution and Conservation at University College London

22. Toonen RJ, Hughes S (2001) Increased throughput for fragmentanalysis on an ABI Prism® 377 automated sequencerusing a membrane comb and STRand software. Biotechniques31:1320-1325

23. Belkhir K, Borsa P, Chikhi L, Raufaste N, Bonhomme F (2013)GENETIX 4.05, logiciel sous Windows TM pour la génétiqu edes populations. Laboratoire Génome, Populations, Interactions,CNRS UMR 5171, Université de Montpellier II, Montpellier 24. Raymond M, Rousset F (1995) GENEPOP (version 4.2): population genetics software for exact tests and ecumenicism. J Heredity 86:248-249

25. Dufresne F, Stift M, Vergilino R, Mable BK (2014) Recent progressand challenges in population genetics of polyploid organisms:an overview of current state-of-the-art molecular and statisticaltools. Mol Ecol 23:40-69. https ://doi.org/10.1111/mec.12581 


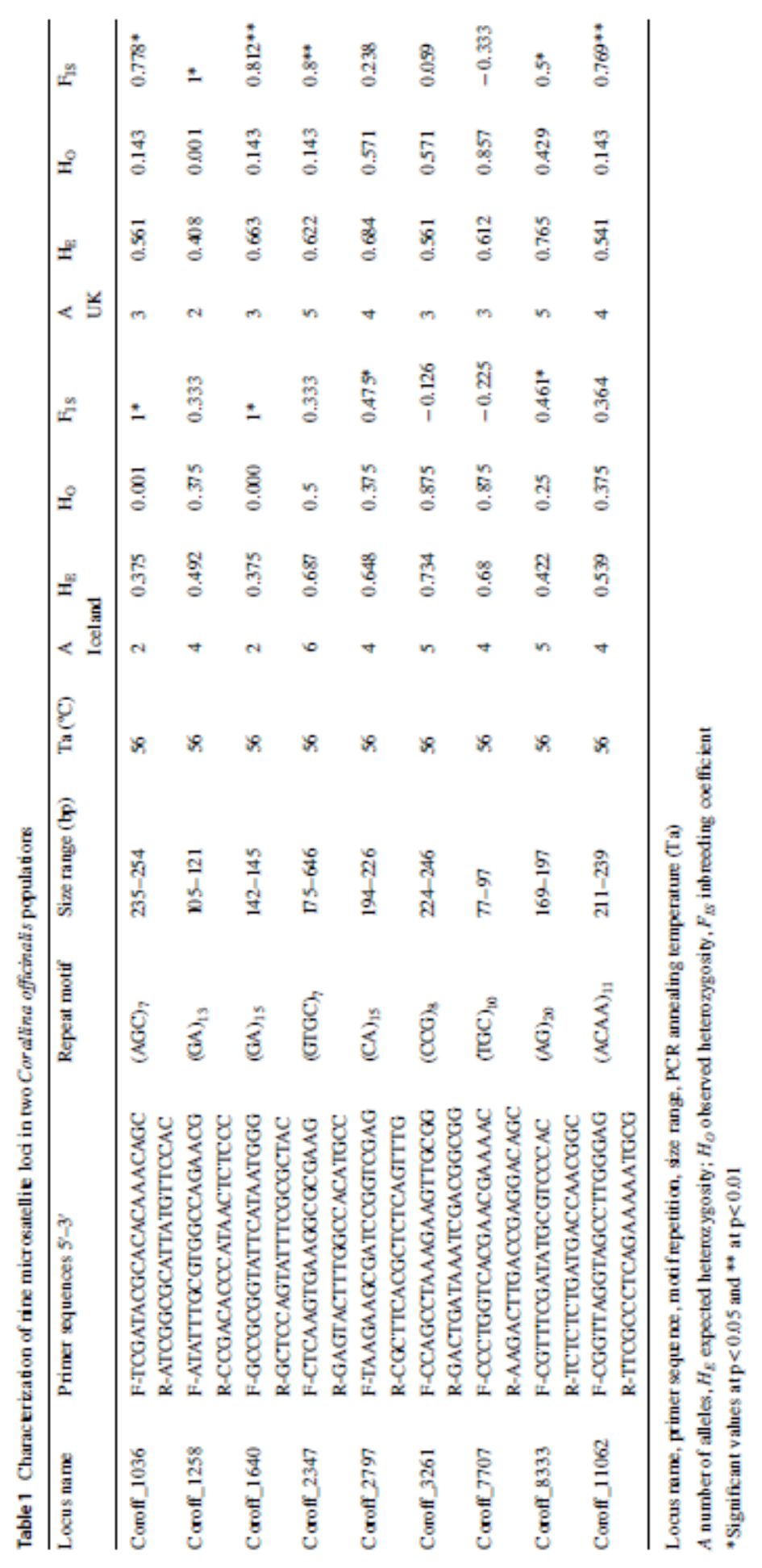

